\title{
What is the Degree of Convergence among Developed Equity Markets?
}

\author{
Ekaterina Dorodnykh \\ University of Rome Tor Vergata \\ Via Columbia 2 - 00133 Rome - Italy \\ Tel: +39-067-259-5911＜wide>E-mail: ekaterina.dorodnykh@uniroma2.it
}

Received: March 14, $2012 \quad$ Accepted: March 30, $2012 \quad$ Published: April 15, 2012

doi:10.5430/ijfr.v3n2p2 URL: http://dx.doi.org/10.5430/ijfr.v3n2p2

\begin{abstract}
The paper investigates the degree of sensitivity of international equity market returns, using MSCI indices as widely tracked global equity benchmarks of stock exchanges, traded throughout the world. In particular, using a time-varying methodology, the research examines whether the returns of developed international equity markets are each associated with movements of MSCI World Index in order to see the level of bilateral influence between equity markets, affected by globalization processes. The model contains the Kalman filter and, as a consequence, it accommodates fundamental shifts in the bilateral relationships. The results show that all analyzed developed equity markets are moving toward greater integration in terms of increasing correlation, they are interdependent and affected by globalization processes, showing strong and lasting relationships between each other. However, bilateral convergence of international equity markets is not an equal process, where different cluster of markets are engaged in different manners.
\end{abstract}

Keywords: Globalization, Equity Markets, Bilateral Convergence, Kalman Filter

\section{Introduction}

The effects of globalization in the world economy and its role within financial markets were widely analysed by the literature (Shahrokhi, 1998; Aggarwal, 1999; Aggarwal et al., 2010; Kearney and Poti, 2005; Eun and Lee, 2010). The pros and cons of international economic and financial framework featured by common trends and higher similarities were considered from different perspectives. Moreover, different concepts and definitions of globalization were provided as well. In the literature the hypothesis that globalization is growing within world economies is commonly adopted by many scholars, however, papers that tried to analyse this phenomenon in a comprehensive manners are just a few. Thus, if the presence of globalization in financial markets could be considered as a commonplace, the need to evaluate the relevance and the developing path of this phenomenon is quite clear.

In this paper the authors try to fill this gap, providing both (1) a measure of globalization within financial markets around the world in order to understand its main trends, and (2) an analysis of single geographical areas in order to understand if globalization is developing as a homogeneous phenomenon or - on the contrary - globalization effects are stronger in some stock markets than others.

The presence of bilateral convergence among international equity markets, caused by globalization processes, suggests the important indications for effective portfolio diversification models. Thus, the need to evaluate the relevance and the developing path of this phenomenon is quite clear. In this paper the author tries to fill this gap, providing a measure of globalization effect within developed equity markets in order to understand its consequences in terms of bilateral convergence.

The paper is organized as follows. A review of the literature on globalization and convergence of international equity markets is provided in order to analyse these concepts and to highlight results from previous studies. A description of data and methodology explanation will follow, while the results of the analysis will be provided and discussed in the result section. In the final section some conclusions and remarks are provided.

\section{Literature Review}

The meaning of globalization was widely analyzed by the literature from both economic and non-economic perspectives. Due to the huge interest on this topic and the different possible manners to analyze it, the need to provide a clear definition of this phenomenon and a specific perspective of the analysis is clear. 
A wide economic definition of globalization is provided by Bhagwati (2004). The author defines globalization as a process of integration of national economies into an international economy through trade, foreign direct investments, capital flows, migration and the spread of technology. The different aspects taken into account highlight how much globalization is a complex phenomenon and suggest the need to focus on a specific topic. In this paper the authors will analyse the financial aspects of globalization and they will refer to the integration of stock-exchanges. However, as Carrieri et al. (2003) pointed out, the globalization concerns both economic and financial aspects and can not be ignored that equity market integration is part of a bigger reform effort that includes the financial sector, the economy as well as political processes. For instance, Friedman and Shachmurove (2005) provide evidence of further integration of the European stock markets after the introduction of the Euro and recently Aggarwal et al. (2010), showed that equity market integration is driven by market forces but constrained by regulatory barriers.

In order to analyse the financial aspect of globalization a definition of what integration means is useful. For the European Central Bank (Trichet, 2005) stock market integration is the market condition where all potential market participants with the same relevant characteristics face a single set of rules when dealing with financial instruments or services, have equal access to financial instruments or services, and are treated equally when they are active in the market. If this definition could be seen from a global financial consumer perspective, a more country specific definition can be proposed as well. Pieper and Vogel (1997), talking about integrated markets, refer to a status of markets where investors can buy and sell in one country and without restriction equities that are issued in another country and as a result identical securities are issued and traded at the same price across markets (after adjustment for foreign exchange rates). Hence, the authors highlight the relevance of cross-country trading and recall macroeconomic principle as the "law of one price". Similarities with this definition of stock market integration exist with the definition proposed by Bekaert and Harvey (2003). For these authors in integrated equity markets, domestic investors are able to invest in foreign assets and foreign investors in domestic assets; hence, assets with identical risks show the same expected return, regardless of trading location. This perspective is coherent with the concepts of integration of Bhalla and Shetty (2006). They argue that when two or more markets are integrated, events in one market will have their impacts felt in the other ones. For these authors integration should be related and measured by effectiveness of information in the price changing more than the presence of trading barriers within different exchanges.

The great interest by the literature on financial market integration and globalization is justified by the positive effects that integrated financial markets could provide. Many authors studied these effects related both to economic and financial topics. Prasad (2003) also highlights that international financial integration can promote growth in developing countries and also helps countries to reduce macroeconomic volatility, while Beck et al. (2000) support the view that better functioning financial intermediaries improve resource allocation and accelerate total factor productivity growth with positive repercussion for long-run economic growth. In a more financial perspective Erdogan (2009) provided evidences that, due to the integration of stock markets, the firms' cost of capital decreases, helping them to solve capital raising problems. Even Trichet (2005), provides that financial market integration, by enhancing competition and efficiency of intermediaries in their operations and allocation of resources, contributes to financial stability; thus, a more integrated international financial framework will arise. The role of stock exchanges in the financial markets and their relationships with financial market integration was also analysed by the literature. Indeed some economists support the belief that globalization encourages the convergence of financial markets. For example, Armanious (2005) shows how an increasing globalization of the world economy should obviously have an impact on the behaviour of national stock markets, which in turn will push the stock exchanges to merge together in order to make economic growth.

Based on the definition related to the "law of one price", investors should consider in portfolio diversification approach that stock market integration implies the following convergence of assets' returns, issued in different countries and generating identical cash flows (Bekaert and Harvey, 1997; Adjouté and Danthine, 2003). In fact, most of studies support a high degree of integration among international equity markets in recent years.

European equity markets show, especially high degree of integration, proved by many scholars. For example, Adam et al. (2002), Baele et al. (2004), and Portes and Rey (2005) not only formulated the different definitions of European equity convergence, but also provided the evidence about the enhanced role of the common currency within Europe for the equity market convergence. Hanousek and Filer (2000), Egert and Kocenda (2005) and Cappiello et al. (2010) also showed that integration strengthened significantly in the European Union countries.

Analysing the convergence at the international level, Piesse and Hearn (2002) and Cerny (2004) found a weaker degree of integration for the Asian emerging equity markets. By contrast, Yang et al. (2003a) argued that that occured only over the post-Asian crisis period. Aggarwal and Kyaw (2005), investigating the convergence trends of three North American Free Trade Agreement (NAFTA) economies, found co-integration between equity prices only over the period after the 
formation of NAFTA, while Darrat and Zhong (2005) argued that the NAFTA formation contributed to a greater speed of convergence among NAFTA members. Ciner (2006) as well identified a high degree of convergence among North American equity markets, especially during the 1990s, on the basis of the boom in information technology stocks and by the dismantling of trade barriers. Finally, Chukwuogor-Ndu (2007) and Chukwuogor-Ndu and Kasibhatla (2007) also confirmed the convergence patterns for North American equity markets.

The recent studies on globalization between international stock markets provide that globalization is a heterogeneous phenomenon where different cluster of countries are engaged in different manners (Nicolini and Dorodnykh, 2011). The pervious works also demonstrate that convergence is also overstepped the continental barriers, where Caporale el al. (2009) provided the evidence of a global convergence/divergence process for five EU countries (Germany, France, the Netherlands, Ireland and the UK) as well as the US over the period 1973-2008, which was not obviously influenced by EU policies. Furthermore, the empirical findings of Apergis et al. (2010) suggest that international equity markets do not form a homogeneous convergence club. Since a country's equity market aggregates the markets of individual industries, these findings may reflect specific endogenous characteristics within industries that prevent convergence at the industry level rather than country-specific factors.

There are different approaches used by the literature to investigate the extent of convergence in international equity markets. Some authors have applied asset-pricing models of integration to determine whether equity returns reflect global rather than local risk factors as a measure of convergence (Bekaert and Harvey, 1995; Karolyi and Stulz, 2002). Furthermore, another approach is based on country-specific industrial effects in convergence among equity markets (Baca et al., 2000; Cavaglia et al., 2000). However, most of the scholars consider the strong effect of EU factors on following convergence among European stock markets (Fratzscher, 2002; Cappiello et al. 2010; Rahman and Khan, 2009; Yang et al, 2003b). Another group of scholars have applied $\sigma$-convergence analysis in order to investigate the presence of convergence. In particular, Babetskii et al. (2007) found the evidence of substantial stock-market integration with respect to new members of the EU. Phillips and Sul (2007) proposed a new econometric approach to test for convergence and the identification of convergence clubs. Apergis et al. (2010), using this methodology, showed more numerous stock-price convergence clubs in certain industries. The authors suggested that industry factors played a more important role in explaining the actual divergence in stock prices than does the stock market itself.

However, interrelated relationships between globalization of international stock markets and the following convergence suggest the possibility to apply the approach of bilateral convergence in order to estimate the extent of convergence between equity markets relative to the global market. In sum, as Hall (1992) pointed out that in order to catch the bilateral convergence through the relative long-run behavior of a number of time series and the simultaneous analysis, the Kalman filter should be used. Harvey (1990) suggested that the Kalman filter estimates the state space model with gradual adjustment of correlations where parameters follow random walks. As a consequence, the model accommodates fundamental shifts in the bilateral relationships. The use of the Kalman filter to test for convergence between capital markets has been used extensively by many authors (Frazer et al., 1994; Bekaert and Campbell, 1995; Serletis and King, 1997; Fraser and Oyefeso, 2001; Manning, 2002, Lee 2008; Lee 2009; Dorodnykh, 2010). However, there is no study where the Kalman filter methodology is used to examine time-varying convergence of relative to the global stock market. Thus, this paper investigates the bilateral relationships between international equity markets returns; additionally contribute to the literature on stock exchange convergence.

\section{Data and Methodology}

The time-varying analysis of global bilateral convergence uses the weekly MSCI equity indices from 1995 to 2010 . The data source is Datastream (Thomson Financial). In particular, the analysis uses the MSCI World Index as an index of global equity market, designed to measure the equity market performance of 24 developed market country indices. Time series were collected for following 24 markets: Australia, Austria, Belgium, Canada, Denmark, Finland, France, Germany, Greece, Hong Kong, Ireland, Israel, Italy, Japan, Netherlands, New Zealand, Norway, Portugal, Singapore, Spain, Sweden, Switzerland, the United Kingdom, and the United States. Data are all in US dollars. The use of weekly data provides more than 800 observations for each index. Furthermore, weekly data collection has been done in order to smooth data from daily noise.

From the time series of MSCI Indices continuously compounded returns for 25 indexes have been calculated as:

$R_{t}=\ln P_{t}-\ln P_{t-1}$

Full descriptive statistics for data (number of observations, minimum and maximum values, standard deviation, skewness, kurtotis and Jarque-Bera tests) are reported in Table 1.

$<$ Table 1 about here $>$ 
The summary statistics using weekly MSCI indexes for overall period provide that Finland shows the highest mean return over the full period while Ireland shows the lowest one. Finland and World are respectively the indexes with the lowest and the highest standard deviations. All indexes show negative skewness, suggesting the lack of data symmetry and indicating that left tail is longer and the mass of distribution is concentrated on the right, where Denmark demonstrates especially negative skewness. Significantly positive kurtosis is shown by all indexes with a clear "fat tails" effect. Australia demonstrates a non-normal and "peaked" distribution of index returns, as Jarque-Bera test confirms.

In order to investigate the relationships between 24 developed equity markets and global equity market correlation analysis was applied.

Traditionally, academic researchers and professionals use the correlation of returns measure to investigate the degree of integration (high correlation) or segmentation (low correlation) between financial markets across national boundaries and across assets classes to evaluate the potential benefits from international portfolio diversification (Markowitz, 1952; Elton and Gruber, 1995; Eichholtz et al.1996 and 1998; Liu and Mei, 1998; Conover, et al. 2002;). According to Schindler (2009) the main examinations of benefits from diversification and portfolio optimization are based on correlation analysis. The correlation coefficient is the common practice of measurement of stock market co movements of stock returns in a given time period, and is widely exploited by the literature (Longin and Solnik 1995, Hassan and Naka 1996, Karolyi and Stulz 2001, Wälti 2006, Schindler and Voronkova 2010). According to the Pearson product-moment correlation coefficient (the "Pearson's correlation), the correlation index has been calculated by dividing the covariance of two index returns by the product of their standard deviations:

$\rho_{X, Y}=\operatorname{corr}(X, Y)=\frac{\operatorname{cov}(X, Y)}{\sigma_{X} * \sigma_{Y}}=\frac{E\left[\left(X-\mu_{X}\right)\left(Y-\mu_{Y}\right)\right]}{\sigma_{X} * \sigma_{Y}}$

Where $E$ is the expected value operator, cov means covariance and corr is a widely used alternative notation for Pearson's correlation.

The methodology is based on the model suggested by Frazer (1994), where security market convergence can be estimated by bilateral differences in their returns. It means that if the security returns in country $\mathrm{X}$ converging to those in country Y, overtime then the bilateral differences in their returns should be diminishing. However, if returns of the securitized in country $\mathrm{X}$ are converging with those of country $\mathrm{Z}$ the bilateral returns of $\mathrm{X}$ with $\mathrm{Y}$ should be increasing.

The following equation expresses the statement:

$(R z-R x)_{t}=\alpha+\beta(R z-R y)+\varepsilon_{t}$

where $R_{Z}$ is the continuously compounded returns of country $Z ; R_{X}$ is the continuously compounded returns of country $X$; $\mathrm{R}_{\mathrm{Y}}$ is the continuously compounded return of country $\mathrm{Y} ; \varepsilon_{\mathrm{t}}$ is a random error term; and $\alpha$ and $\beta$ are the parameters of interest. of country $\mathrm{Y} ; \varepsilon_{\mathrm{t}}$ is a random error term; and $\alpha$ and $\beta$ are the parameters of interest.

Later Frazer et al. (2008) use as an initial framework this model with two relationships in order to estimate the bilateral convergence between New Zealand, Australia and various other Pacific-Basin equity markets. Lee $(2008 ; 2009)$ and Dorodnykh (2010) have applied the same model to study the convergence processes in markets.

Thus, the model can be adopted for estimation of bilateral convergence between developed international equity markets relative to the global equity market.

$$
\begin{aligned}
& \left(r^{\text {Global }}-r^{1}\right)_{t}=\alpha_{1 t}+\beta_{1 t}\left(r^{2}-r^{\text {Global }}\right)+\varepsilon_{1 t} \\
& \left(r^{2}-r^{1}\right)_{t}=\alpha_{2 t}+\beta_{2 t}\left(r^{2}-r^{\text {Global }}\right)+\varepsilon_{2 t}
\end{aligned}
$$

where $r^{\text {Global }}$ is the continuously compounded returns of associated with MSCI World Index; $r^{1}$ is the continuously compounded returns of developed equity market of country $1 ; r^{2}$ is the continuously compounded return of developed equity market in country $2 ; \varepsilon_{t}$ is a random error term; and $\alpha_{i}$ and $\beta_{i}(\mathrm{i}=1,2)$ are the parameters of interest. In particular the $\beta_{i}$ are associated with convergence. If equity market in country in 1 was perfectly converged with global equity market, the equations $(1,2)$ could be estimated using standard OLS fixed parameter estimation, and $\left(r^{\text {Global }}-r^{1}\right)$ would be independent of $\left(r^{2}-r^{\text {Global }}\right)$, and $\left(r^{2}-r^{1}\right)$ and $\left(r^{2}-r^{\text {Global }}\right.$ ) would be perfectly positively correlated. This implies that the joint restriction $\beta_{1}=0$ and $\beta_{2}=1$ should hold. Similarly, if a market in country 2 and equity market in country 1 were perfectly converged, the joint restriction $\beta_{1}=-1$ and $\beta_{2}=0$ would be expected. The term "perfectly converged" indicates that the two markets sustain movements of the same direction and magnitude. 
However, the convergence is a process and not a state, it means that profiles of $\alpha$ and $\beta$ are allowed to evolve over time according to the following laws of motion. The model can be estimated via the Kalman filter that allows a gradual path of adjustment:

$$
\begin{aligned}
& \left(r^{\text {Global }}-r^{1}\right)_{t}=\alpha_{1 t}+\beta_{1 t}\left(r^{2}-r^{\text {Global }}\right)+\varepsilon_{1 t} \\
& \alpha_{1 t}=\alpha_{1 t-1}+\eta_{1 t} \\
& \beta_{1 t}=\beta_{1 t-1}+v_{1 t} \\
& \left(r^{2}-r^{1}\right)_{t}=\alpha_{2 t}+\beta_{2 t}\left(r^{2}-r^{\text {Global }}\right)+\varepsilon_{2 t} \\
& \alpha_{2 t}=\alpha_{2 t-1}+\eta_{2 t} \\
& \beta_{2 t}=\beta_{2 t-1}+v_{2 t}
\end{aligned}
$$

where $\eta_{i t}$ and $v_{i t}(\mathrm{i}=1,2)$ are normally and identically distributed, with a mean of zero and variances of $\sigma^{2}$. As Harvey (1990) suggest, it means that $\alpha_{i t}$ and $\beta_{i t}$ follow random walks. The use of the Kalman filter in estimating time-varying beta in preference to the alternatives, such as GARCH models and the approach of Schwert and Seguin (1990) can be justified from previous studies on the stock market time-varying beta, suggesting that all methodologies are successful at characterizing time-varying beta using the Kalman filter (Brookes et al., 1998; Faff et al. 2000).

The interpretation of $\beta_{1 t}$ and $\beta_{2 t}$ is essentially the same as $\beta_{1}$ and $\beta_{2}$ described above from OLS estimation, except that now the parameters are allowed to vary through time. There is no restriction that $\beta_{2 t}$ is between 0 and 1 ( $\beta_{1 t}$ is between -1 and 0 ). Building on the previous conclusions, if $\beta_{1 t} \rightarrow-1$ and $\beta_{2 t} \rightarrow 0$ this indicates that relationship of equity market in country 1 with equity market in country 2 has strengthened over time, alternatively $\beta_{1 t} \rightarrow 0$ and $\beta_{2 t} \rightarrow 1$ indicate that the equity market in country 1 has converged more with global equity market than with the other 23 developed equity markets from the sample. The following identity between bilateral spreads:

$\left(r^{\text {Global }}-r^{1}\right)=\left(r^{2}-r^{1}\right)-\left(r^{2}-r^{\text {Global }}\right)$

It implies that movements in one bilateral spread are associated with movements in one or other of the remaining bilateral spreads in the stylized three member system. An adding-up constraint of the form $\beta_{2 t}-\beta_{1 t}=1$ exists. This adding-up constraint therefore provides an opportunity to assess the robustness of the results.

\section{Results}

Results of correlation analysis estimated over the sampled period are presented in Tables 2.

\section{$<$ Table 2 about here $>$}

Table 2 shows that over the full period all analyzed markets have significant high correlation with global equity market (MSCI World Index), suggesting high financial integration. Furthermore, such equity markets like the USA, the UK, Germany and Canada show especially high correlation with global market in full period, while Greece, Israel and New Zealand the lowest one. Financial correlation between 25 analyzed developed equity markets is also significant with the coefficient mean higher then 0.5 , where such markets like the USA, the UK, Germany and Canada again demonstrate considerable integration.

However, correlation analysis is associated with some crucial points resulting in strong limitations on its meaning. Hence, the diversification opportunities can be also investigated via bilateral convergence process.

Using the equations (7) and (8) each of 24 developed equity markets is tested in sample of other markets to check the level of the convergence relative to the Global market (MSCI World Index). The parameters $\beta_{1 t}$ and $\beta_{2 t}$ indicate the extent of convergence.

The results for full period 1995-2010 of the Kalman filter values $\beta_{2 t}$ are shown in Table 3, since the $\beta_{1 t}$ values give essentially the same information but the $\beta_{1 t}$ values are easier to interpret, i.e. if Global market is converging with one of international equity markets $\beta_{2 t} \rightarrow 1$, however, if Global market is not converging with developed equity markets $\beta_{2 t} \rightarrow$ 0 . In the analysis the adding-up constraint $\beta_{2 t}-\beta_{1 t}=1$ is satisfied by the data, with deviations typically less than 0.0001 . Moreover, the constraint $\alpha_{1 t}=\alpha_{2 t}$ is also satisfied. Thus, the estimation procedure would appear to be robust to the weighting between the state equations. The statistical measurements of variability like standard deviation and t-test were 
added in the analysis of bilateral convergence in order to show the stability of obtained relationships and the significance of experimental results. In this way, standard deviation values show the stability of relationship over time and t-test estimation allows checking the probability of convergence.

$<$ Table 3 about here $>$

The effect of globalization on convergence of equity returns relative to the global equity market is presented in Table 3 . Analyzing the bilateral relationships between 24 developed equity markets relative to the MSCI World Index, the results show that the returns in overall period demonstrate significant bilateral convergence between most of the national markets, which is tending to 1 . Moreover, the values of standard deviation also indicate the stability of these relationships and are confirmed by the results of $t$-test.

Such equity markets like New Zealand, Austria and Ireland relative to the global equity market with coefficients $(0.850)$, $(0.849)$ and (0.842) respectively, demonstrate the highest average time-varying beta coefficients. These findings suggest that equity returns of these markets are highly affected by the returns of the other 23 equity markets from the sample. Furthermore, the lowest average time-varying beta coefficients are found in the relationships for the UK/Global and the USA/Global with beta coefficients $(0.335)$ and $(0.4892)$ respectively, suggesting that stock returns in these countries are less influenced by the other equity markets.

Analyzing the bilateral relationships between equity markets relative to the global market, it could be noticed that returns in Australia are mostly affected by returns of the UK and the US markets, while the lowest influence is estimated by returns of Hong Kong and Norway. In case of Austria/Global the best convergence is registered with Singapore, Hong Kong and the UK, and the lowest influence on Austrian stock returns is found from Belgium. The returns in Belgium are mostly affected by the USA, Australia and Hong Kong, while the most insignificant result is found for Sweden. Canada/Global bilateral relationships have very high convergence with all markets, especially, with New Zealand, Australia and Ireland. However, Canadian stock returns are less affected by movements in Finland. Returns in Denmark relative to the Global equity market are affected by returns in Hong Kong and New Zealand. Moreover, the low convergence is found with the returns in Belgium. In the bilateral relationships between Finland and Global market, the returns of Dutch and French stock markets play an important role, while returns of New Zealand seem to be less significant. French returns relative to the Global equity market are mostly influenced by the USA, Portugal and Israel; whereas, Finland and Sweden demonstrate even negative convergence. of Germany shows significant convergence with Australia, the USA and Singapore, while returns of Finland and Sweden again demonstrate negative convergence. In relationships between Greece/Global, French and Norwegian returns have significant influence on Greek returns, while the US and Israel markets show the lowest coefficients in terms of significance. The returns in Hong Kong appear to be mostly influenced by returns of Australia and Sweden and less affected by returns of Belgium. The returns of the stocks in Ireland are mostly affected by the UK, France and Finland, while the most insignificant result is found for Hong Kong. In relationships between Israel/Global, the perturbations in French and German markets have influence on the returns, while Austria and Hong Kong show the lowest beta coefficients. Italy/Global bilateral relationships have high convergence tending to 1 with the the USA, Portugal and Singapore, while Italian stock market is less affected by movements in Sweden. Japan returns relative to the Global equity market are mostly influenced by Australia and Sweden; whereas, Hong Kong demonstrates the less significant convergence of its returns. The Netherlands appears to be mostly influenced by the returns in the USA, Australia and Portugal and have negative convergence with Finland. The returns of the stocks in New Zealand are mostly affected by the UK and Australia, while the most insignificant result is registered with Hong Kong. In relationships between Norway/Global, again the UK and Australia influence on its stock returns, where Hong Kong shows the lowest coefficients in terms of significance. Returns in Portugal relative to the Global stock market are affected by movements in the UK and the USA, while Belgium, Greece and Hong Kong show low impact. Returns of Singapore shows significant convergence with Australia and the UK, while with the returns of Hong Kong demonstrate negative convergence. In relationships between Spain/Global, movements in Australian and the US markets have influence on Spanish returns, meanwhile Finland shows the lowest coefficients in terms of significance. The returns in Sweden appear to be mostly influenced by the returns of Denmark and the UK and less affected by returns Hong Kong market. The returns of the stocks in Switzerland are mostly affected by Japan, the USA and Australia, while the negative convergence is found with Sweden and Finland. In relationships between UK/Global, Japan and New Zealand have the highest influence, while Sweden and Finland again show the negative coefficients of convergence. Finally, the USA/Global bilateral relationships have high convergence with Denmark, New Zealand and Austria and they are not affected at all by movements in Finland and Sweden.

The obtained results demonstrate that such equity markets like the USA and the UK have the highest influence on other European and Asian stock market returns in terms of bilateral convergence, while such equity markets like Hong Kong, 
Sweden, Finland and Belgium have the lowest influence. Furthermore, some stock markets like Hong Kong, Sweden, Finland and Belgium have very low influence on globalized international stock markets, showing even negative convergence with some markets. Thus, increased globalization and integration between international equity markets and following convergence suggest that portfolio diversification models, using geographical criteria in equity asset allocation models, should also follow industry diversification approach for efficient international asset-allocation models and add new emerging markets.

\section{Conclusions}

Using the MSCI Indexes from 24 developed international equity markets and Global equity market (MSCI World Index), correlation and convergence analyses have been applied in order to highlight the relevance of the globalization trend in international equity markets and to analyze the level of bilateral influence in terms of convergence. A comparison between the average correlation coefficients for each equity market in overall period highlights that integration in terms of correlation between developed equity markets around the world is growing by the time.

Furthermore, the obtained results confirm that the globalization of financial markets in the last three years is quite stronger than in the previous years, suggesting that the globalization effect on the correlation matrixes is speeding up. The increased integration in terms of correlation is found between the US and Canadian equity markets, within European markets and within Asian markets. Moreover, the findings suggest very significant correlation between analyzed equity markets with the Global market (MSCI World), starting from late-90's.

The potential diversification benefit is the main reason to include international assets in a portfolio due to the risk minimizing. However, the world's economies are becoming more and more integrated, shifting the diversification benefits. Data from convergence analysis of equity returns relative to the Global equity market provide that the analyzed markets in overall period demonstrate high positive convergence between each other with the beta coefficients tending to 1 . Results of the paper are consistent with results provided in the literature by the previous studies. In fact, many scholars have suggested that equity markets moving toward greater integration. The contribution of current research confirms the increased globalization between international equity markets and the following convergence relative to global market. Thus, portfolio diversification models, using geographical criteria in equity asset allocation models, should also follow the new emerging markets and industry diversification approach in developed markets for allocation models.

Moreover, the findings provide that the returns of New Zealand, Austria and Ireland are highly affected by the returns of other 23 markets from the sample, while the returns of the UK and the USA are less influenced by the other equity returns relative to the global market in full period. These data are also confirmed the results of expanded investment opportunity. According to Clark (2011) still, some investors have a tendency to shy away from international investments because of geopolitical concerns, the fact that less information is immediately available, or simply because people are less familiar with international investing. Although the U.S. and the UK markets are still the largest in the world, there are still developing countries outside which can be considered for portfolio diversification, where the growth in these emerging markets appears to be especially promising.

The obtained could be interesting for both investors and academics to know if international stock exchange returns converging or not. For academics the obtained results show the importance of further research in terms of spill over effects between highly integrated developed equity markets and factors related to the reasons of different level of convergence between engaged markets; meanwhile, for investors the extent of high convergence between international developed equity markets implies new models with emerging markets for the efficient long-term asset allocation.

\section{References}

Adam, K., Jappelli, T., Menichini, A., Padula, M. and Pagano, M. (2002). Analyze, Compare and Apply Alternative Indicators and Monitoring Methodologies to Measure the Evolution of Capital Market Integration in the European Union. Report to the European Commission.

Adjaoute, K. and Danthine, J. P. (2003). European Financial Integration and Equity Returns: A Theory-Based Assessment. FAME Research Paper Series, International Center for Financial Asset Management and Engineering.

Aggarwal, R. and Kyaw, N. A. (2005). Equity Market Integration in NAFTA Region: Evidence from Unit Root and Cointegration Tests, International Review of Financial Analysis 14, pp. 393-406. http://dx.doi.org/10.1016/j.irfa.2004.10.008

Aggarwal, R., 1999. Technology and Globalization as Mutually Reinforcing Forces in Business, Management International Review, 39(2), 83-104. 
Aggarwal, R., Lucey, B., Muckley, C., 2010. Dynamics of Equity Market Integration in Europe: Impact of Political Economy Events, Journal of Common Market Studies, 48(3), 641-660. http://dx.doi.org/10.1111/j.1468-5965.2010.02067.x

Apergis, N., Christou, C. and S. M. Miller. (2010). Country and Industry Convergence of Equity Markets: International Evidence from Club Convergence and Clustering, Working papers 2010-33, University of Connecticut, Department of Economics

Armanious, A. (2005). Globalization Effect On Stock Exchange Integration, Cairo University.

Babetskii, I., Komarek, L. and Komarkova, Z. (2007). Financial Integration of Stock Markets among New EU Member States and the Euro Area, Czech Journal of Economics and Finance 57, pp. 341-362.

Baca, S. P., Garbe, B. L. and Weiss, R. A. (2000). The Rise of Sector Effects in Major Equity Markets, Financial Analyst Journal 56, pp. 34-40. http://dx.doi.org/10.2469/faj.v56.n5.2388

Baele, L., Ferrando, A., Hordhal, P., Krylova, E. and Monnet, C. (2004). Measuring Financial Integration in the Euro Area, Oxford Review of Economics 20, pp. 509-530.

Beck, T., Levive, R. and Loeysa, N. (2000). Finance and the Sources of Growth, Journal of Financial Economics (1-2), pp.261-300. http://dx.doi.org/10.1016/S0304-405X(00)00072-6

Bekaert, G. and Harvey, C. R. (1995). Time-Varying Conditional World Market Integration. Journal of Finance, pp. 403-444.

Bekaert, G. and Harvey, C. R. (1997). Emerging Equity Market Volatility, Journal of Financial Economics 43, pp. 29-77.

Bhagwati, J., (2004). In Defense of Globalization, Oxford, New York: Oxford University Press.

Brooks, R.D., Faff, R.W. and Ariff, M. (1998). An investigation into the extent of beta instability in the Singapore stock market, Pacific-Basin Finance Journal, Vol. 6, pp. 87-101. http://dx.doi.org/10.1016/S0927-538X(97)00025-5

Caporale, G. M., Erdogan, B. and Kuzin, V. (2009). Testing for Convergence in Stock markets: A Non-Linear Factor Approach, Discussion Paper No. 932, Deutsches Institut fur Wirtschaftsforschung, Berlin.

Cappiello, L., Kadareja, A. and Manganelli, S. (2010). The Impact of the Euro on Equity Markets, Journal of Financial and Quantitative Analysis, Cambridge University Press, Vol. 45(02), pp. 473-502, http://dx.doi.org/10.1017/S0022109010000086

Carrieri F., Errunza V. and Hogan K. (2007). Characterizing World Market Integration Through Time, Journal of Financial and Quantative analysis, Vol. 42 (4), pp. 915-940.

Cavaglia, S., Brightman, C. and Aked, M. (2000). The Increasing Importance of Industry Factors, Financial Analysts Journal, pp. 31-39. http://dx.doi.org/10.2469/faj.v56.n5.2389

Cerny, A., (2004), Stock Market Integration and the Speed of Information Transmission, CERGE-EI Working Paper Series, No. 242.

Chukwuogor-Ndu, C. (2007). Stock Market Returns and Volatilities: A Global Comparison, Global Journal of Finance and Banking Issues 1, pp.1-17.

Chukwuogor-Ndu, C. and Kasibhatla, K. (2007). Post NAFTA Integration of North American Stock Markets: Implications for Financial Decision Making, North American Journal of Finance and Banking Research 1, $37-53$.

Ciner, C. (2006). A Further Look at Linkages between NAFTA Equity Markets, The Quarterly Review of Economics and Finance, Vol. 46, pp. 338-352. http://dx.doi.org/10.1016/j.qref.2006.02.007

Clark, J. (2011). Is It Time To Rethink International Investments?, Structured Investing: Portfolio Perspectives, Loring Ward.

Conover, C., Friday, H. and Sirmans, G. (2002). Diversification benefits from foreign real estate investments", The Journal of Real Estate Portfolio Management, Vol. 8 (1), pp. 1-25.

Darrat, A. F. and Zhong, M. (2005). Equity Market Linkages and Multinational Trade Accords: The Case of NAFTA, Journal of International Money and Finance 24, pp. 793-817.

Dorodnykh, E. (2010). European Real Estate Markets: The Extent of Bilateral Convergence in the European Real Estate Markets, Lambert Academic Publishing. ISBN-13: 978-3838351506. 
Egert, B. and Kocenda, E. (2007). Interdependence between Eastern and Western European Stock Markets: Evidence from Intraday Data, Economic Systems 31, pp. 184-203. http://dx.doi.org/10.1016/j.ecosys.2006.12.004

Eichholtz, P., Huisman, R. Koedijk, K. and Schuin, L. (1998). Continental Factors in International Real Estate Returns, Real Estate Economics, Vol. 26, pp. 493-509. http://dx.doi.org/10.1111/1540-6229.00754

Eichholtz, P.. (1996), Does International diversification work better for real estate than for stocks and bonds?, Financial Analyst Journal, Vol. 52 (1), pp. 56-62. http://dx.doi.org/10.2469/faj.v52.n1.1967

Elton, E. J. and Gruber, M. J. (1995). Modern Portfolio Theory and Investment Analysis, J. Wiley and Sons, New York.

Erdogan B. (2009). How Does European Integration Affect the European Stock Markets?, Working Paper / FINESS 1.1a, DIW Berlin, German Institute for Economic Research.

Eun, C., Lee J., 2010. Mean-variance convergence around the world, Journal of Banking \& Finance, Vol. 34 (4), pp. 856-870. http://dx.doi.org/10.1016/j.jbankfin.2009.09.016

Faff, R.W., Hillier, D. and Hillier, J., (2000), Time-Varying Beta Risk: An Analysis of Alternative Modeling Techniques, Journal of Business Finance and Accounting, Vol. 27, pp. 523-555. http://dx.doi.org/10.1111/1468-5957.00324

Fraser, P. and Oyefeso, O. (2001). The UK Stock Market's Relationship with US and European stock markets: Is the UK Stock Market Snuggling-up to the US - or to Europe?, University of Otago, Department of Finance Seminar Series, Dunedin, New Zealand.

Fraser, P. McAlevey, L. and Tayler, M. (2008). The New Zealand Markets Relationship with Australia and Pacific-Basin Share Markets: is New Zealand Converging with Australia?, Applied Financial Economics, Vol. 18 (6), pp. 451-462. http://dx.doi.org/10.1080/09603100600993745

Fraser, P., Helliar, C.V. and Power, D.M., (1994), An Empirical Investigation of Convergence among European Equity Markets, Applied Financial Economics, Vol. 4, pp. 149-157. http://dx.doi.org/10.1080/758523959

Fratzacher M. (2001). Financial Market Integration in Europe: on The Effects of EMU on Stock Markets, International Journal Of Finance And Economics, Vol. 7, pp. 165-193. http://dx.doi.org/10.1002/ijfe.187

Hall, S.G., Robertson, D. and Wickens, M.R. (1992). Measuring Convergence of the EC Economies, The Manchester School, Vol. 60, pp. 99-111. http://dx.doi.org/10.1111/j.1467-9957.1992.tb01463.x

Hanousek, J. and Filler, R. (2000). The Relationship between Economic Factors and Equity Markets in Central Europe, Economics of Transition, Vol. 8, pp. 623-638. http://dx.doi.org/10.1111/1468-0351.00058

Harvey, A. C. (1990). The Econometric Analysis of Time Series, The MIT Press, Massachusetts institute of Technology, Cambridge.

Hassan M. K. and Naka A. (1996). Short-run and long-run dynamic linkages among international stock markets, International Review of Economics and Finance, Vol 5, (1), pp. 387-405. http://dx.doi.org/10.1016/S1059-0560(96)90025-8

Karolyi, G. A. and Stulz, R. M. (2002). Are Financial Assets Pricesd Locally or Globally?, NBER Working Paper Series, No. W8994.

Kearney, C., Poti V., 2005. Correlation Dynamics in European Equity Markets, Finance 0507008, EconWPA.

Lee, S.L. (2008). The extent of the convergence in Asian Real Estate Markets, Cass Business School, City of London University.

Lee, S.L. (2009). Is the UK real estate market converging with the rest of Europe?, Journal of European Real Estate Research, Vol. 2 (1), pp.18-32. http://dx.doi.org/10.1108/17539260910959536

Liu, C.H. and Mei, J., (1998). The predictability of international real estate markets, exchange rate risks and diversification consequences, Real Estate Economics, Vol. 26 (1), pp. 3-39. http://dx.doi.org/10.1111/1540-6229.00736

Longin F. and Solnik B. (1995). Is the correlation in international equity returns constant: 1960 - 1990, Journal of International Money and Finance, Vol 14, pp. 3-26. doi:10.1016/0261-5606(94)00001-H, http://dx.doi.org/10.1016/0261-5606(94)00001-H

Manning, N. (2002). Common Trends and Convergence? South East Asian equity Markets, 1988-1999, Journal of International Money and Finance, 21, pp. 183-202. http://dx.doi.org/10.1016/S0261-5606(01)00038-9 
Markowitz, H. M. (1952). Portfolio selection, Journal of Finance, Vol. 7(1), pp.77-91. http://dx.doi.org/10.2307/2975974

Nicolini, G. and Dorodnykh E. (2011). How much Globalization is there in the World Stock Markets and where is it?, Working Paper, University of Rome Tor Vergata.

Phillips, P. C. B. and Sul, D. (2007). Transition Modeling and Econometric Convergence Tests. Econometrica 75, 1771-1855. http://dx.doi.org/10.1111/j.1468-0262.2007.00811.x

Pieper, P. and Vogel, R. (1997). The Stock Market Integration In Latin America, CAER II Discussion Paper №. 21, Harvard Institute for International Development.

Piesse, J. and Hearn, B. (2002). Equity Market Integration versus Segmentation in Three Dominant Markets of the Southern African Customs Union: Cointegration and Causality Tests, Applied Economics 14, pp. 1711-1722. http://dx.doi.org/10.1080/00036840110119448

Portes, R. and Rey, H., Wei S. J., Winters, A. (2005). The Determinants of Cross-Border Equity Flows, Journal of International Economics 65, pp. 269-296. http://dx.doi.org/10.1016/j.jinteco.2004.05.002

Prasad, E.,. Rogoff, K,. Wei, S.J and. Kose, M.A. (2003). The effects of financial globalization on developing countries: Some empirical evidence, IMF Occasional paper 220.

Rahman, M. and Khan, M. M. (2009). The Euro and Convergence Among Stock Markets of Germany, France and Italy, Global Economy Journal, Vol. 9, pp. 1-13. http://dx.doi.org/10.2202/1524-5861.1434

Schindler, F. (2009). Long-term Benefits from Investing in International Real Estate, Discussion Paper № 09 - 023 , Centre for European Economic Research.

Schindler, F. and Voronkova, S. (2010). Linkages between international securitized real estate markets: Further evidence from time-varying and stochastic cointegration, ZEW Discussion Papers, 10 - 051.

Schwert G and Seguin, P. (1990). Heteroskedasticity in stocks returns, Journal of Finance, Vol. 45 (11), pp. 29-55. http://dx.doi.org/10.2307/2328718

Serletis, A. and King M. (1997). Common Stochastic Trends and Convergence of European Union Stock Markets, The Manchester School, Vol. 65 (1), pp. 44-57. http://dx.doi.org/10.1111/1467-9957.00042

Shahrokhi, M., 1998. Global financial challenges for the new millenium, Global Finance Journal, Elsevier, Vol. 9(1), 1-4. http://dx.doi.org/10.1016/S1044-0283(98)90011-4

Trichet, J.C. (2005). Reflections on the international financial system, Speech by the President of the European Central Bank.

Walti, S. (2005). The macroeconomic determinants of stock market synchronization, Trinity College, Dublin.

Yang, J., Kolari, J. W. and Min, I. (2003a). Stock Market Integration and Financial Crises: The Case of Asia, Applied Financial Economics, Vol.13, pp. 477-486.

Yang, J., Min, I., and Li, Q. (2003b). European Stock Market Integration: Does EMU Matter?, Journal of Business, Finance and Accounting, Vol. 30, pp. 1253-1276. http://dx.doi.org/10.1111/j.0306686X.2003.05535.x 
Table 1. Summary statistics of weekly returns: $1995-2010$

\begin{tabular}{|c|c|c|c|c|c|c|c|c|}
\hline Index & $\mathrm{s}$ & Mean & Max & Min & $\mathrm{D}$ & Skew & $\mathrm{rt}$ & $\mathrm{B}$ \\
\hline & 34 & & & & 5 & 2 & 2 & 19.1 \\
\hline MSS & 34 & 24 & 51 & 21 & 86 & 88 & 9 & 377 \\
\hline $\bar{M}$ & 34 & 2 & 4 & 1 & 64 & 33 & 3 & 900 \\
\hline $\mathrm{M}$ & & & 1 & -0.229519 & 2 & 73 & 1051.869 & 039 \\
\hline & & & & & & & 10 & o \\
\hline MSC & 4 & & 76 & 51 & 33 & 54 & 34 & 2575 \\
\hline$\overline{\mathrm{MSC}}$ & 34 & 25 & 0.20 & 07 & 91 & 32 & 48 & 5.07 \\
\hline $\mathrm{MSC}$ & 34 & & 49 & 77 & & & & 79.8 \\
\hline$\overline{\mathrm{MSCI} G}$ & 34 & 16606 & 182367 & -0.1649232 & .0350953 & -0.2610926 & 5671.419 & 257.5 \\
\hline & & & 93 & 65 & & & & 38.1 \\
\hline MSCI H & 4 & 24 & 0.25 & -0.2 & 0.04 & 0.0 & 875 & 1149 \\
\hline $\mathrm{N}$ & & & & & & & & 39 \\
\hline & & & 3 & 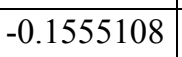 & & & & \\
\hline MSCI & & & 3 & 99 & 65 & 73 & 5 & 289 \\
\hline MSCI & 34 & & 36 & -0.15 & 122 & 91 & .774 & 74.6 \\
\hline MSCI Ne & 4 & 01 & 0.1377261 & -0.1566615 & 0.0328021 & -0.4869645 & 5707.888 & 287.8 \\
\hline $\overrightarrow{\mathrm{SC}}$ & 834 & 21 & 771 & 561 & 688 & 59 & 952 & 273.3 \\
\hline & & & 4 & 4 & 8 & 8 & & 1007 \\
\hline MSCI & & 4 & 8 & 2 & 6 & 4 & 1 & .8 \\
\hline MSCI & 834 & 1 & 5 & 74 & 73 & 76 & 43 & 63 \\
\hline MSCI & 4 & & 0.1 & -0.25 & 0.036 & -0.3529689 & 8077.665 & 13.3 \\
\hline$\overline{\mathrm{M}}$ & 834 & 7 & 0 . & -0.1 & 0.0 & 0 . & 5 & 3.8 \\
\hline MSCI Swi & 834 & 3 & 0 . & 3 & 5 & 3 & 6 & 192.1 \\
\hline MSCI UK & 4 & 89 & 0.18 & -0.1 & 558 & 292 & 176.703 & +2.0 \\
\hline MSCI & 34 & 015871 & 0.1399694 & -0.1404507 & 0.0267728 & -0.0942548 & 6365.462 & 394.8 \\
\hline
\end{tabular}




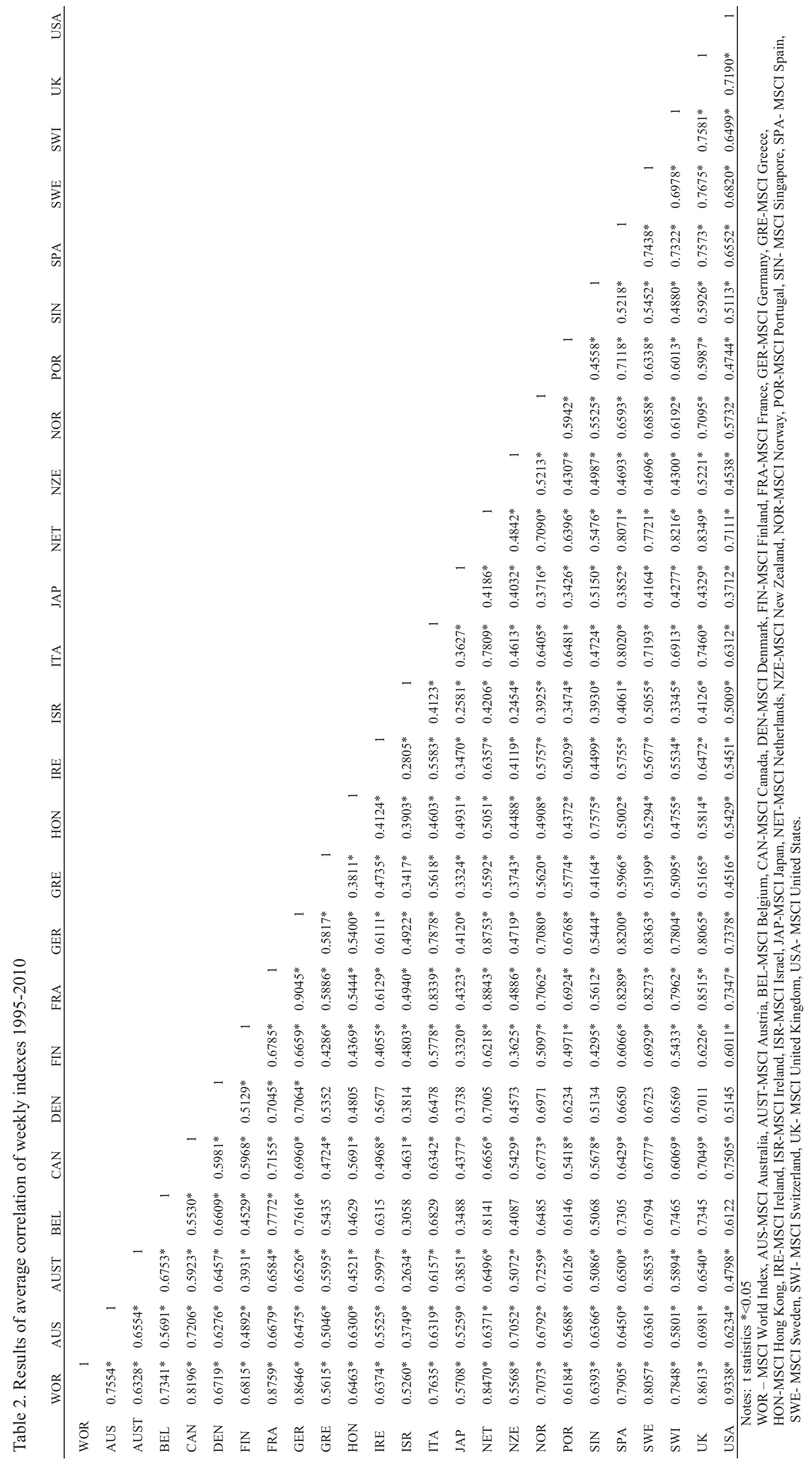




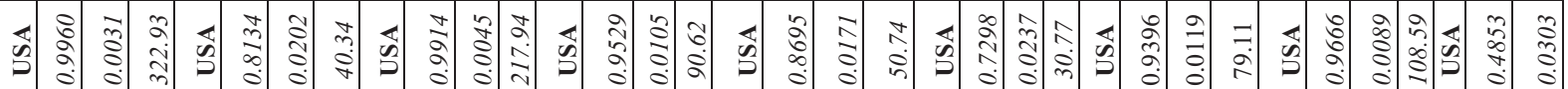

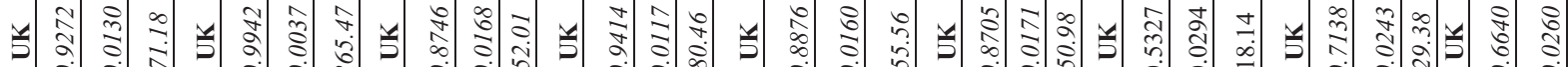

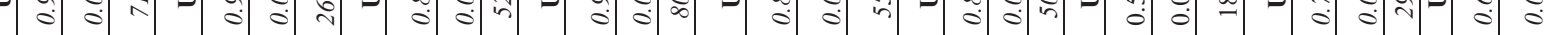

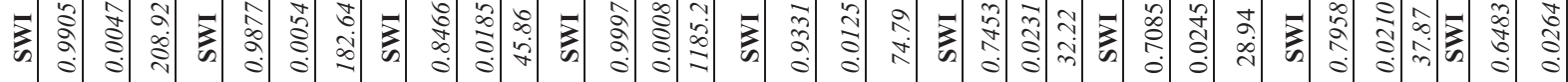

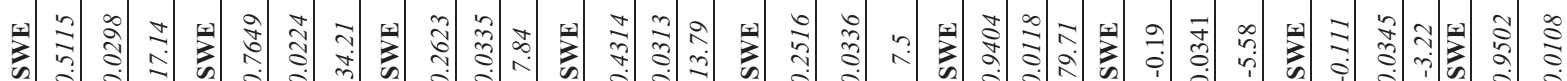
子 $\approx$ क

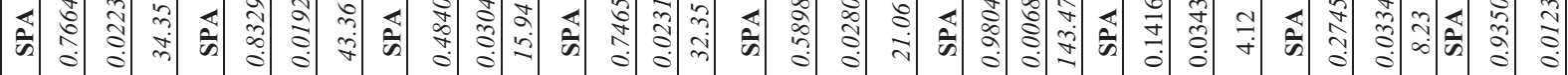

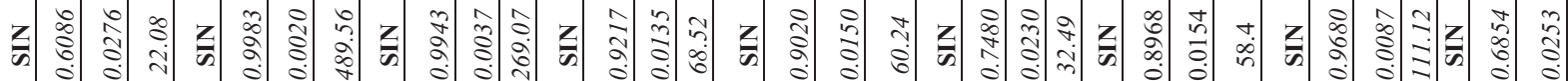

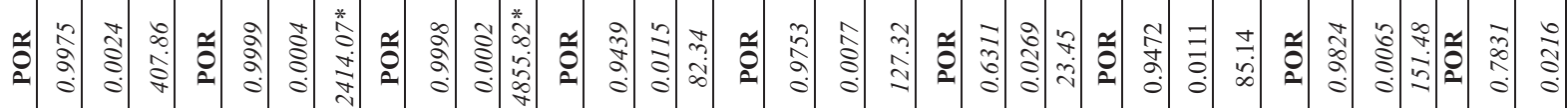
年

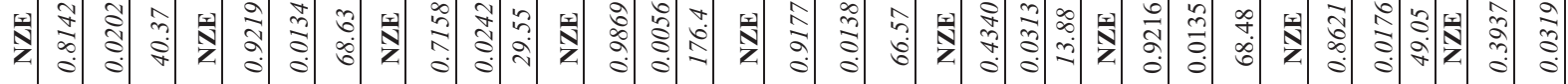

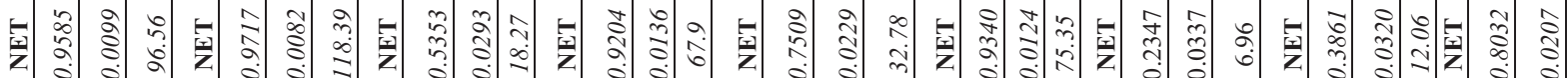

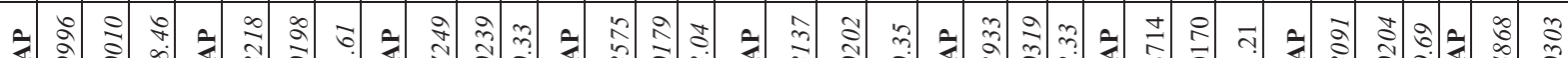

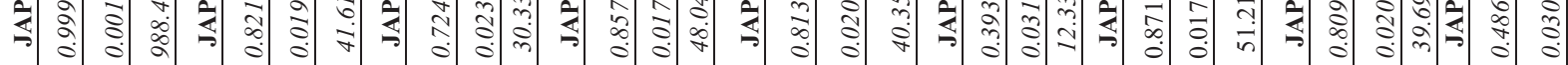

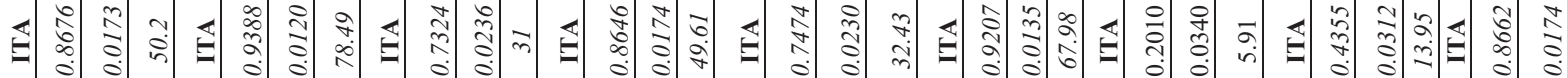
$\approx$ ก

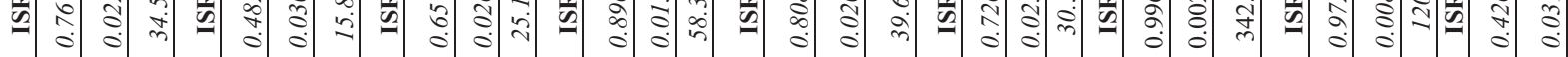

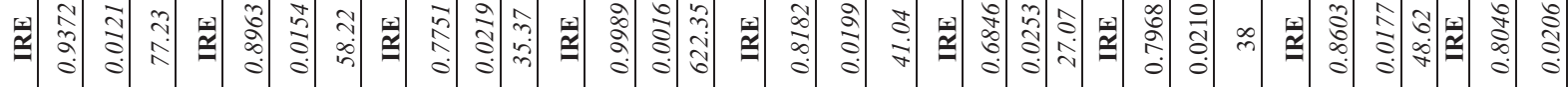

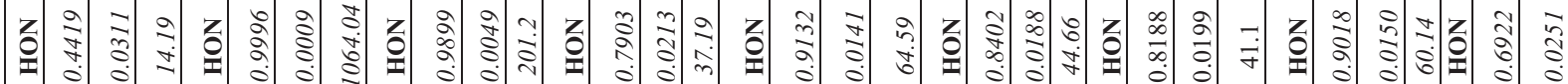

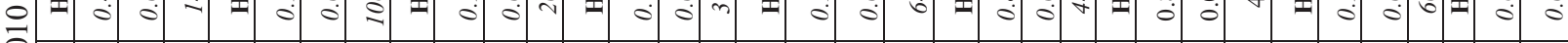
กิ่

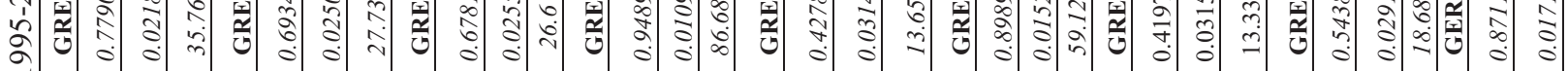

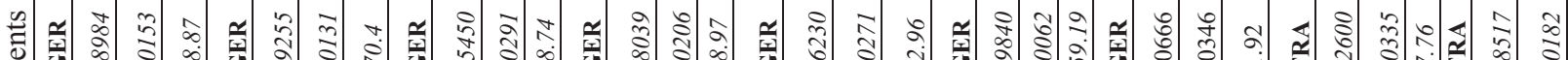

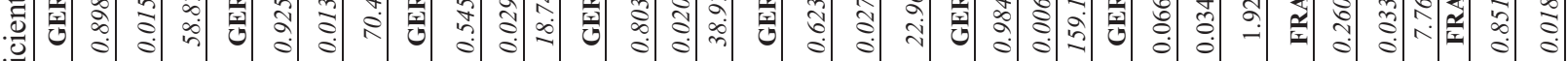

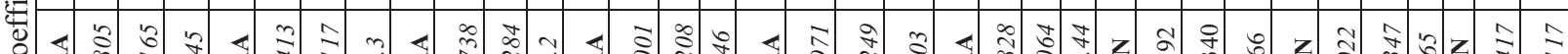

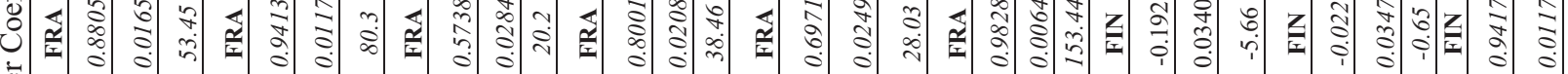

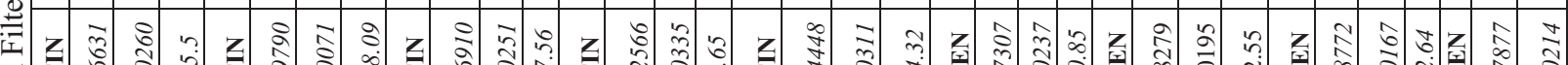

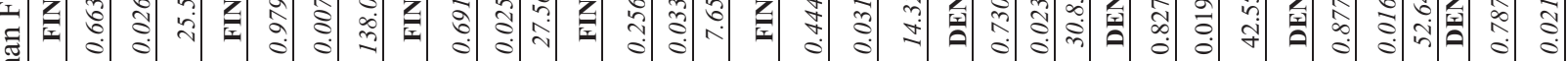
药

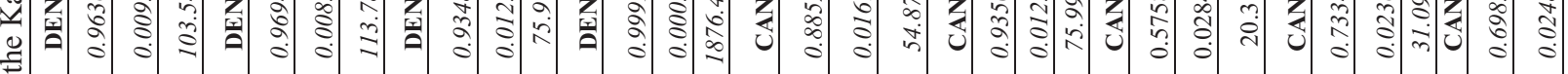

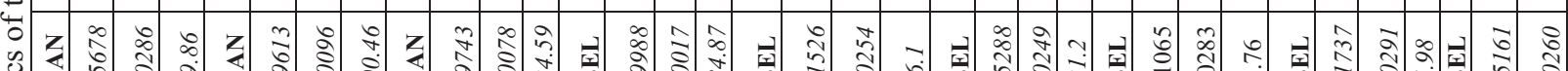

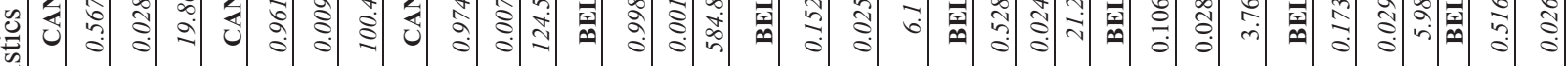
踢

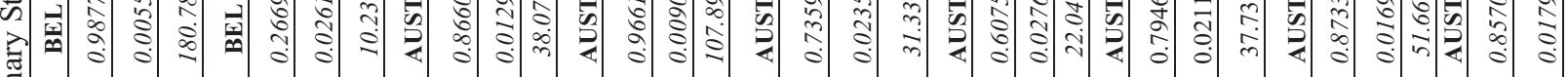

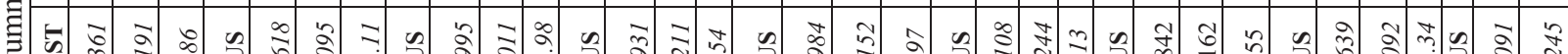

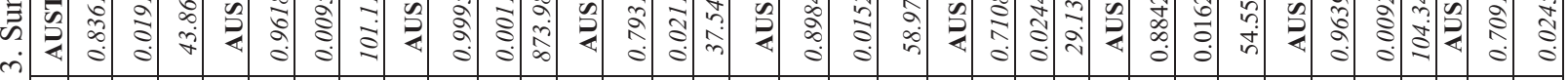

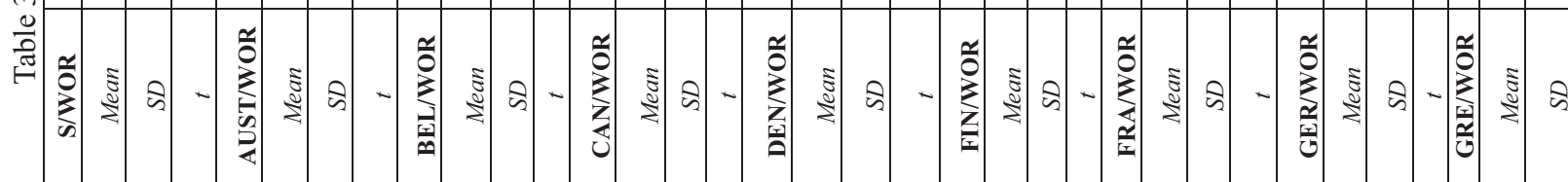




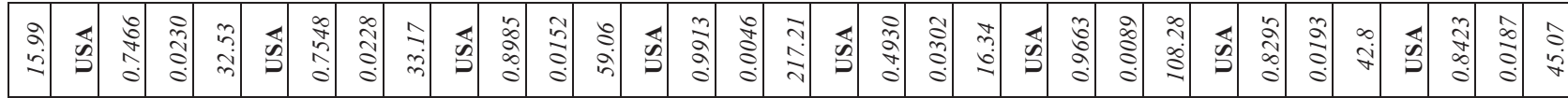

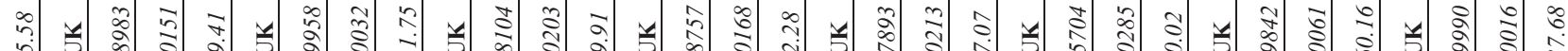

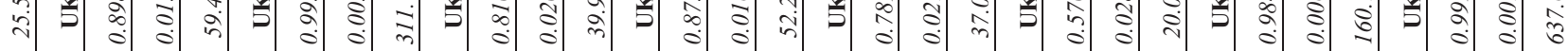

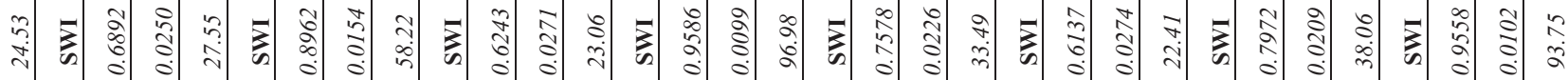

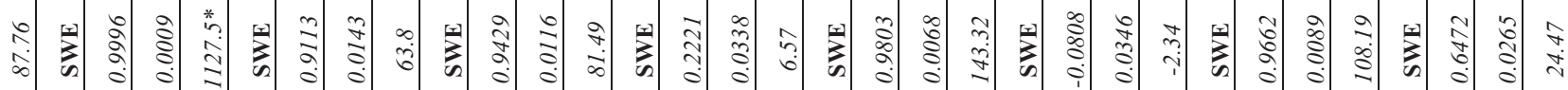

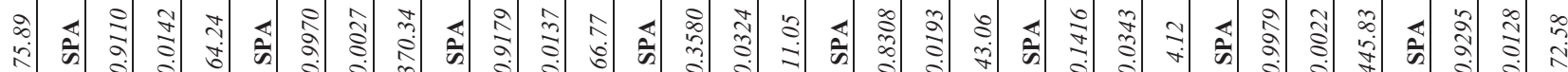

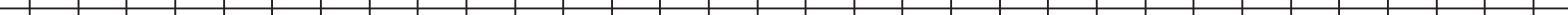

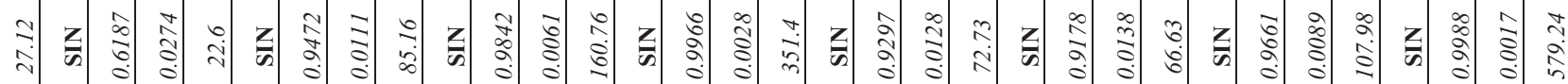
ำ

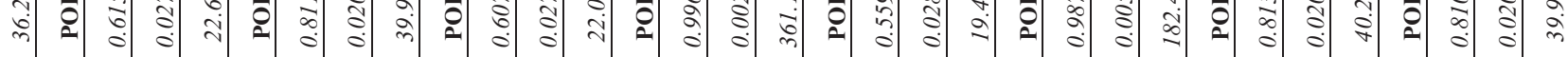

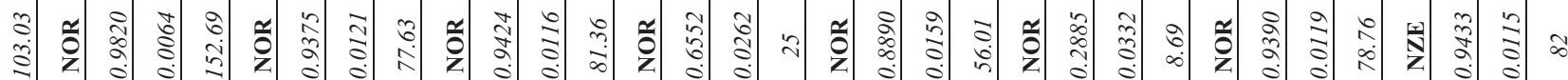

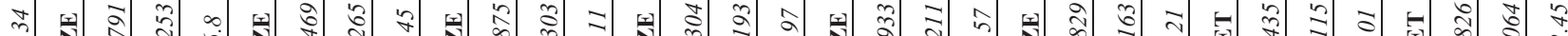

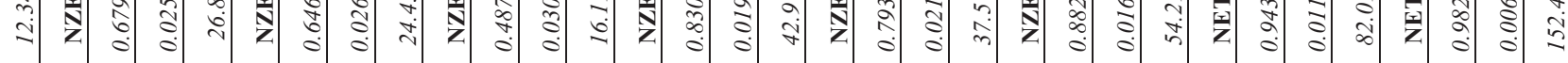

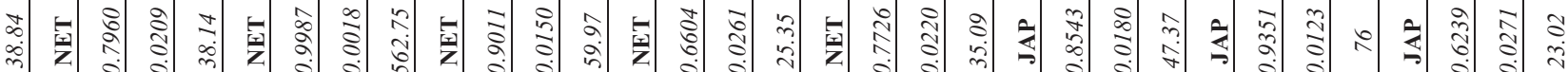

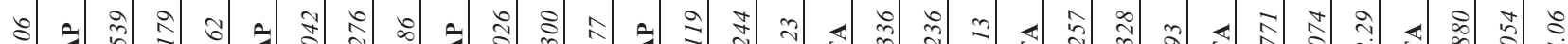

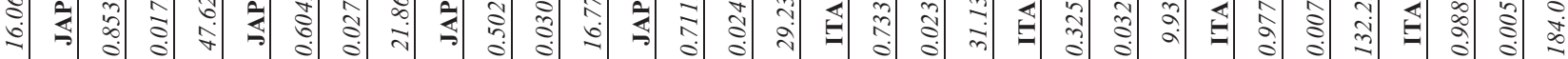

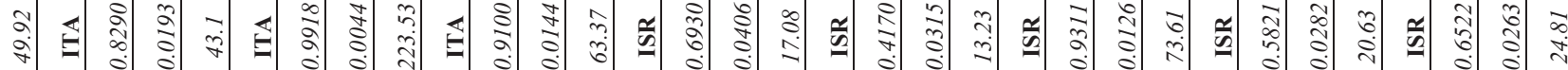

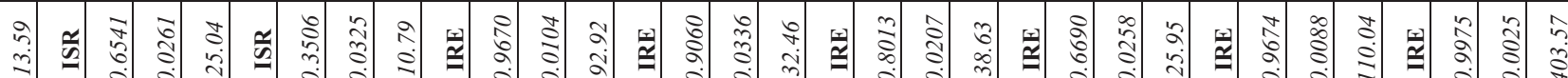

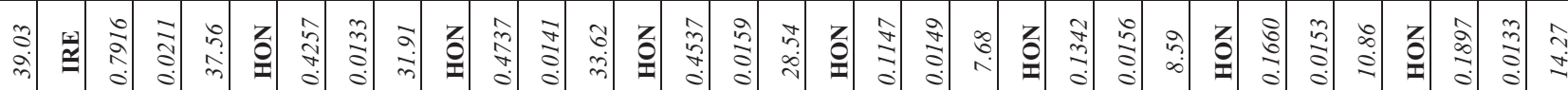

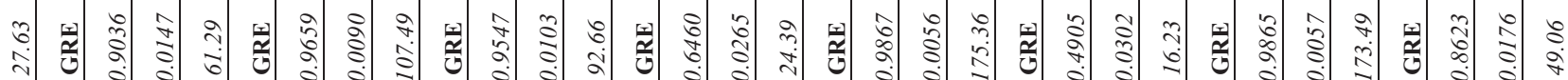

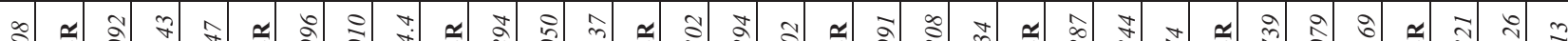
ํํำ

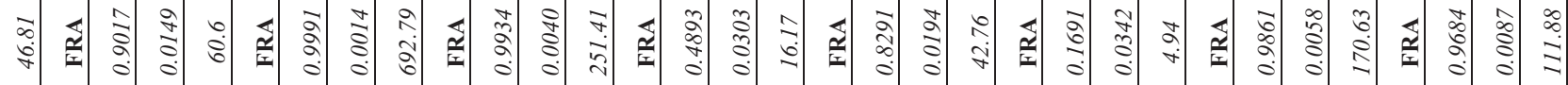

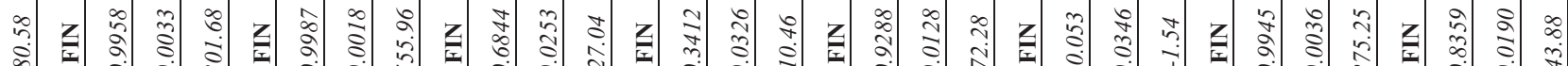

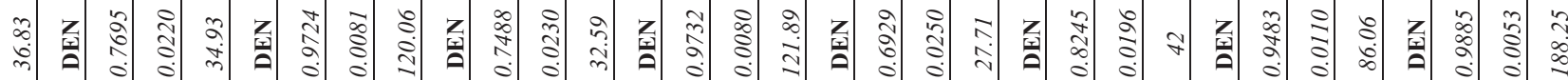

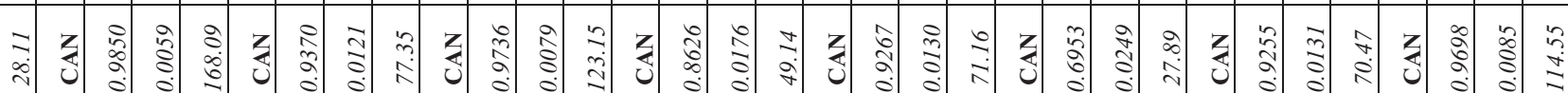

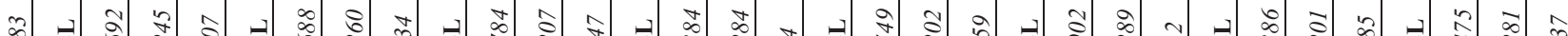

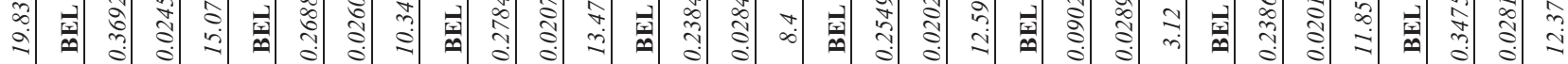

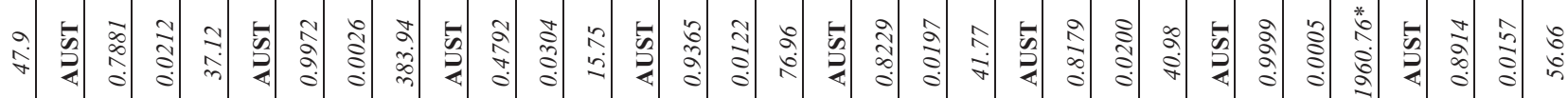

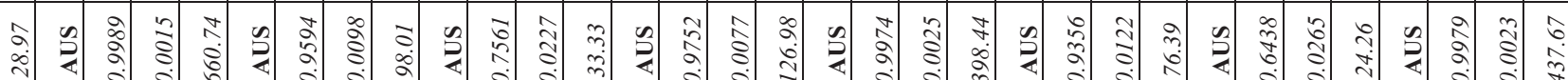

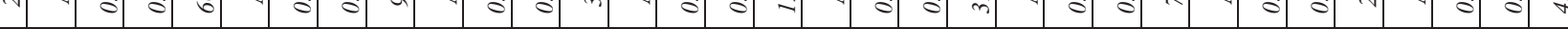

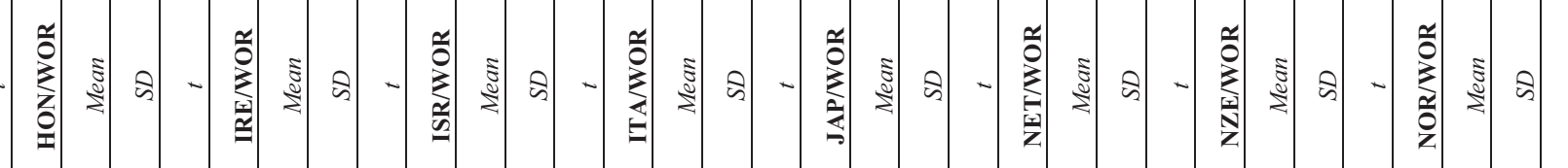




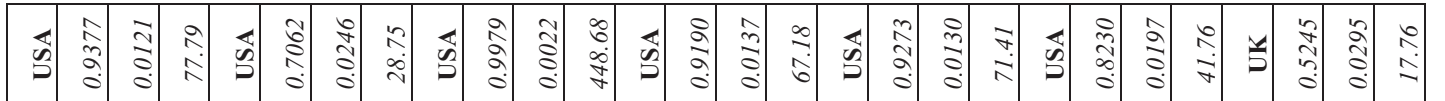

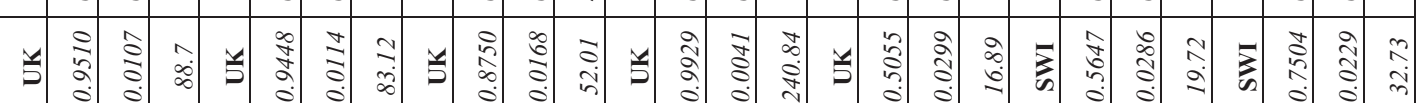

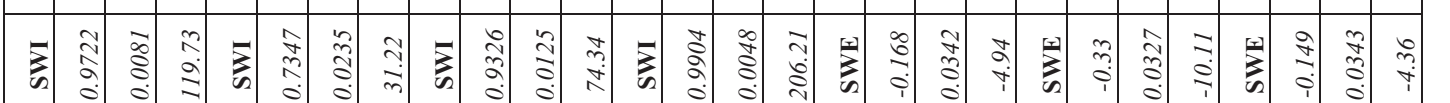

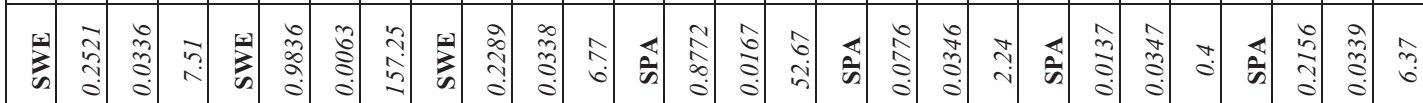

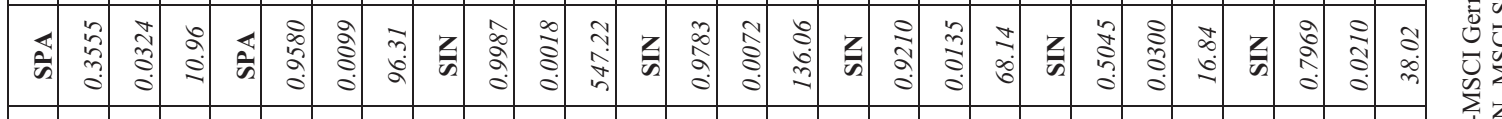

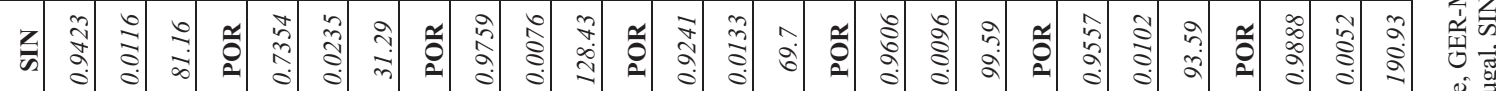
\% ะ

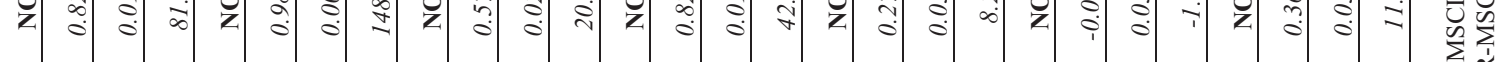

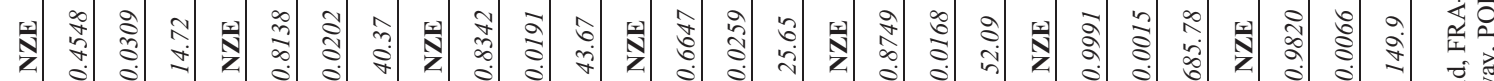

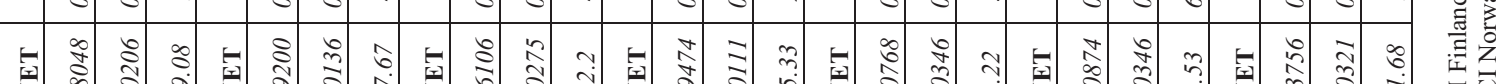

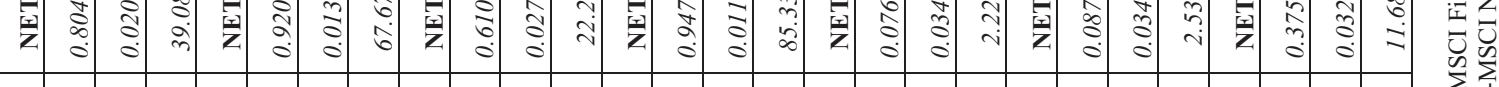

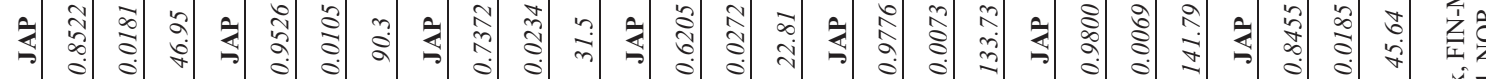

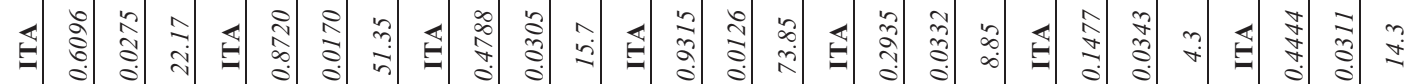

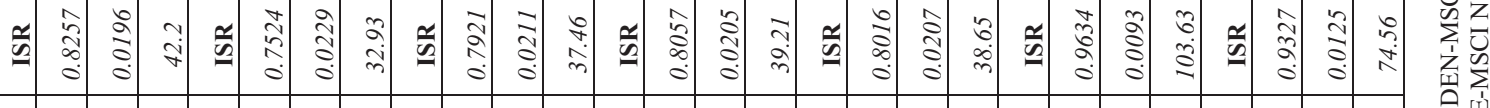

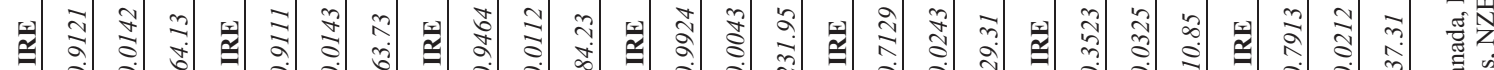

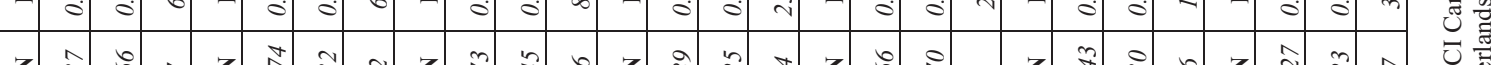

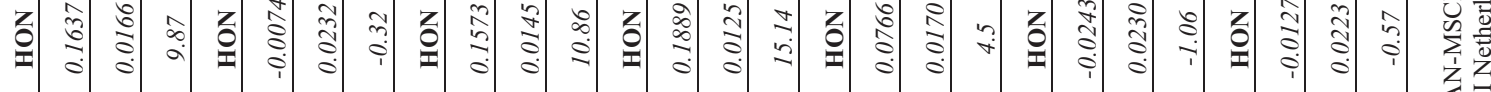

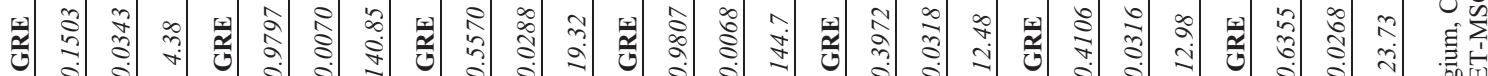
น 은

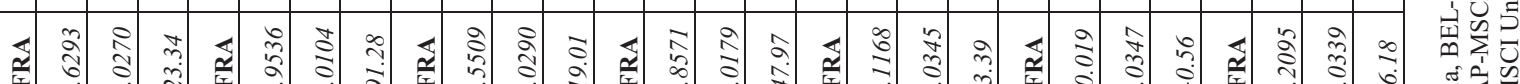

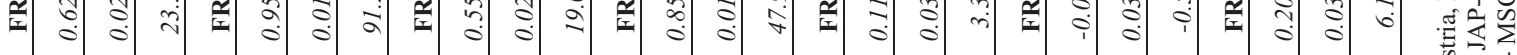

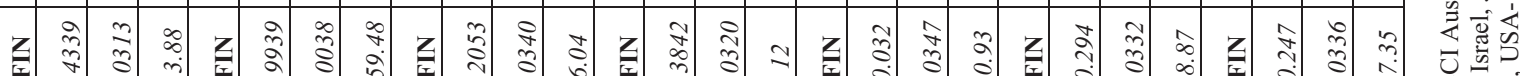

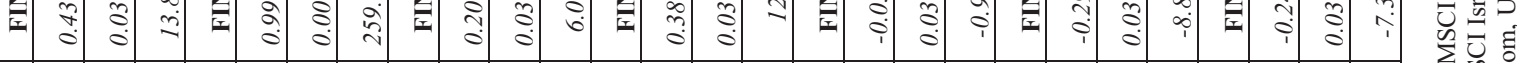

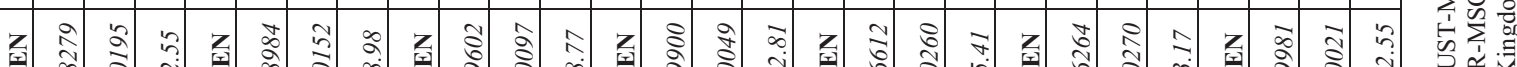

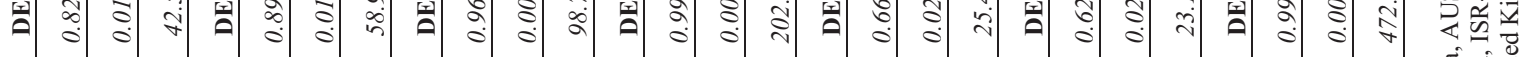

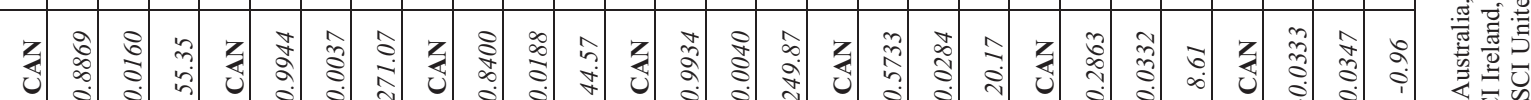

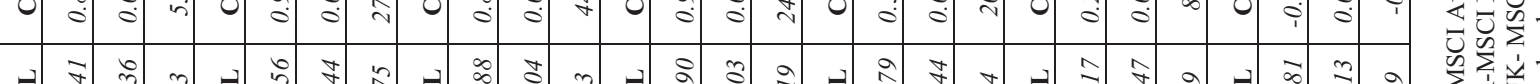

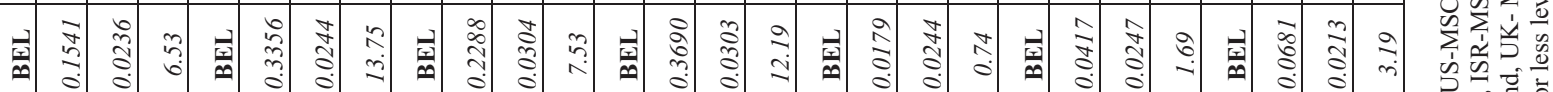

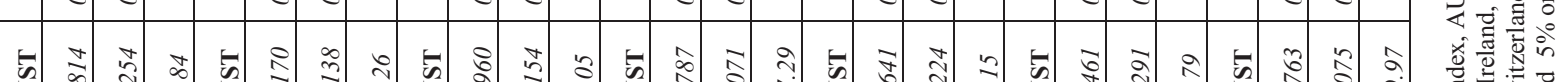

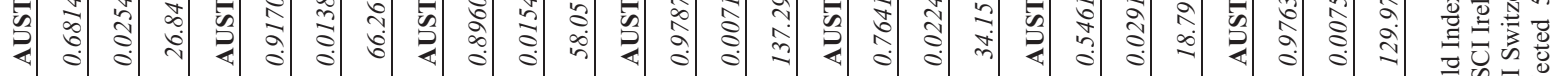

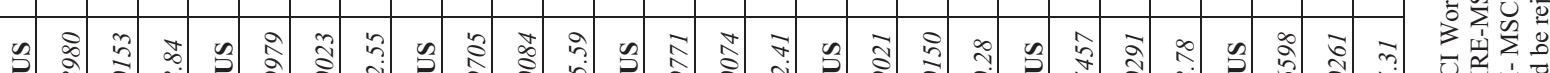

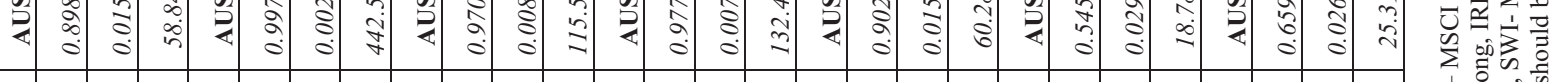

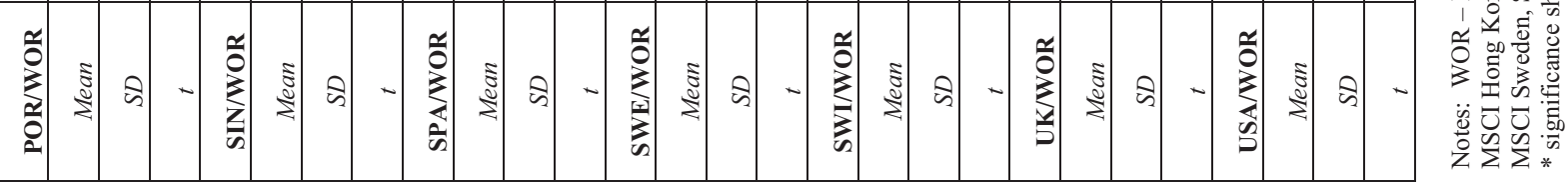

